mediate scale of diffusion, the sort involved in the travel of radioactive material from the Windscale reactor accident in October 1957, little progress has been reported. On this scale, involving heights of several thousands of feet and distances of tens of miles, the processes of dispersal are further complicated on one hand by the variation of the mean wind field with height, and on the other hand by the large-scale effects of thermal stratification, leading alternatively to the virtually complete suppression of vertical spread or to rapid ascent in organized convective motion. From a practical point of view, it is to this scale of processes that attention is most urgently required.

\title{
FUTURE OF MINERAL EXPLORATION IN GREAT BRITAIN AND IRELAND
}

$\mathrm{T}$ HE fourth Sir Julius Wernher Memorial Lecture of the Institution of Mining and Metallurgy was given by Mr. Anton Gray, mining adviser to the U.K. Atomic Energy Authority, at the Royal Institution on September 22, his subject being "The Future of Mineral Exploration". In a survey of the world situation, Mr. Gray maintained that whereas it is unlikely that the present rapid rate of increase of consumption of metals can be maintained, it would not be surprising if the demand for the major metals doubles before the end of the present century. About the beginning of this century the geologist began to take over the work of the prospector, for by then most of the mineral deposits not concealed by younger formations had been found. But he has not had the same success in the search for a method of predicting the occurrence of ore-bodies as his colleague in the petroleum industry has had in finding con. cealed oil-pools.

This results from his inadequate knowledge of the precise mode of origin of mineral concentrations ; for while it is generally agreed that most important ore-bodies were introduced into openings in preexisting rocks by warm waters, there is no agreement as to the source of the water or of the contained metals. The dominant hypothesis, that of hydrothermal solutions related to granite, had been shown, in Mr. Gray's view, to be adequate only for a limited group of metals, including tin, tungsten, beryllium and some gold concentrations. He suggested an unorthodox but not heretical alternative for the other metals : that the waters are generated during metamorphism associated with mountain-building, and he based this suggestion on two of the great ore deposits of the world, the central African copper belt and the Witwatersrand goldfield. The great part which Mr. Gray has played in mineral exploration in central Africa lends authority to his advocacy of this hypothesis of what might be called metamorphic lateral secretion.

This lecture formed a prelude to a symposium on "The Future of Non-Ferrous Mining in Great Britain and Ireland", held at the Federation of British Industries on September 23-24. The symposium consisted of twenty-four papers, in three broad groups : a series of seventeen devoted to descriptions of the geology, mining history and potentialities of the mineralized districts of Ireland, Scotland, England and Wales; a group of short contributions on technical aids to mineral exploration, such as the various geophysical methods, the use of geochemical prospecting techniques and of air photography ; and a series on economics and finance.
The foundation for an approach to the geological problems of the mineral fields was laid during the past century by the official primary 6 -in. Geological Survey of Great Britain and Ireland, but with the decline of the tin, copper and lead mines, there was little further interest in the subject until recently. The Special Reports on Mineral Resources of the Geological Survey, chiefly based on work done during the First World War, brought together much valuable data, but it is probably fair to say that geological investigation by modern methods has been confined to the past two decades. The papers in the first group gave a fair conspectus of the conclusions reached. As is well known, the mineral fields in the British Isles occur in granite and adjacent DevonianCarboniferous slate in the south-western counties of England; and elsewhere chiefly in two main environments, the Lower Palæozoic slates and very low-grade metamorphics; and the unmetamorphosed Lower' Carboniferous rocks, chiefly of limestone or 'Yoredale' facies. A stratigraphical control-that is to say, a strict relationship between particular beds or lithologies and introduced mineral bodies-is postulated by W. J. Hughes in central Wales, by A. A. Archer in north Wales, and by H. G. Dines in west Shropshire, in all these cases in Lower Palæozoic strata; but in other districts where the rocks are of similar age, such as the Lake District (T. Eastwood) or Leadhills-Wanlockhead (R. A. Mackay), no such control has been found. Thus, while the ore-shoots, though steeply inclined, tend to be elongated ribbons where they are related to the stratigraphy, where they are not-as, for example, in the Greenside lead or Coniston copper mines-- the two major dimensions tend to be roughly equal. In the Carboniferous fields of the Pennines and Flint-Denbigh there is a very well-marked relation to brittle beds such as sandstone and limestone, as well as to chemically reactive wallrocks such as limestone and dolerite; and the influence of impermeable or semi-permeable shales or rotted lavas overlying favourable strata is important in localizing ore-bodies. It follows that in these districts, as well as in many Lower Palæozoie fields, ore-bodies occur which fail to outcrop. Some of these have been found by underground operations, but nearly all districts contain areas suitable for prospecting for concealed mineral deposits, some of them of substantial promise. This is the ehief basis for the view that British metalliferous deposits are far from exhausted.

A second line of geological approach is the study of the spatial distribution of mineral species in individual districts. The zonal pattern in Cornwall 
is well known and has been clarified by Dines, as well as in K. F. G. Hosking and J. H. Trounson's contribution to the symposium. Zoning has been demonstrated in the northern and southern Pennines by the present writer, broadly corresponding with the outer zones of Cornwall, but lateral rather than vertical in effect. It can be discerned in individual deposits like Bridford, Devon, described by P. G. L. Vipan, in a downward change from barite to sulphides, and Archer notes a broad though probably not genetic zoning in north Wales.

Most important of all, the localization of introduced mineral deposits is controlled by structural features, particularly by fractures which resulted from successive periods of stress and which form a definite pattern in each field; but also by granite cupolas, by folds of various dimensions and even by pre-ore dykes. At Leadhills-Wanlockhead a thrust plane is recognized as the operative control by Mackay. Displacement of ore-bodies by faulting after emplacement also occurred in many districts in the northern Pennines this may have thickened some oreshoots locally. For Derbyshire it was suggested by W. W. Varvill that definite belts of rich mineralization, oblique to the superficial structure, could be recognized; perhaps these are related to trends in the concealed basement rocks.

Though more detailed structural information is desired in every district, the chief obstacle to suecessful prediction is present ignorance of the origin of the mineralizing fluids and their paths of ascent. A clear genetic relation to granite is demonstrable only in the south-west of England, and here it is interesting to note that Hosking's interpretation of the form of the granite batholith in depth, based on the distribution of mineral veins, corresponds remarkably closely with the quite independent interpretation based on gravity survey recently presented to the Royal Society by M. H. P. Bott, A. A. Day and D. Masson-Smith. There is evidence of concealed granites beneath the northern Pennines from the gravitational data of Bott and Masson-Smith, but the connexion with mineralization remains to be proved by deep boring. In many other districts, no hint has so far been found of such a connexion. There is, however, evidence from boring that mineralization persists to much greater depths than mining has so far reached, for example at Halkyn, described by G. A. Schnellmann, and east of the north Derbyshire district.

The geological age of the deposits has little bearing on their future value, but it is to be noted that on this aspect some new evidence was forthcoming. A. Fowler showed that the Conlig lead vein near Belfast follows a dolerite dyke of probable Tertiary age; while conversely Archer found that a dyke of the same age cuts through a lead lode at Pare in the Conway valley.

The mineral deposits of the Republic of Ireland, described by M. V. O'Brien, include at Avoca a deposit in Lower Palæozoic slates which has been developed with success in recent years, and which promises to be a major source of copper ore and pyrite. This work, financed by the Government and leading to the revival of a dead industry, exercised a considerable influence upon the discussions at the symposium. The small non-ferrous mining industry in the United Kingdom could be expanded if, using the geological basis which is now becoming available, techniques such as electromagnetic and shallow seismic survey, and geochemical soil sampling, were followed up by vigorous boring programmes. J. S. Webb's work at Gregory in Derbyshire showed how a lead deposit, deeply concealed under shale and grit, yet betrayed its presence by a leakage-dispersion at surface. The hope for the future is in the 'concealed areas', a conclusion emphasized by A. J. P. Walter.

The papers contributed to the symposium were available as pre-prints, but a collected volume, including the discussion, is to be published.

K. C. Dunham

\section{THE NATIONAL STANDARDS LABORATORY OF AUSTRALIA DIVISION OF METROLOGY}

$\mathrm{T}$ HE work described in the annual report for 1956-57 of the Division of Metrology of the Australian National Standards Laboratory extends over a wide field and is of interest to the physicist and the engineer, to the laboratory worker and the industrialist, who are concerned with standardization and fine measurement. The primary objects of the work are the maintenance and improvement of the Commonwealth standards, the development of improved techniques of measurement and providing assistance to industry. The need for standardization and co-operation at international level is clearly recognized and accepted as an important responsibility ; considerable effort has been devoted to this end, particularly in the field of length-measurements by the up-to-date techniques of optical interferometry. It has involved world-wide travel to participate personally in deliberations under the auspices of the International Committee of Weights and Measures and of the International Convention for Legal Metrology, and to make personal contact with those engaged in similar work in comparable institutions in other parts of the globe. Incidentally, the report from the section which deals with line standards indicates very clearly the difficulties of establishing and maintaining precise standards of length on the present basis of a material metre bar in the custody of an institution half the world away. Australia will stand to gain as much as any nation from the international adoption, envisaged for 1960 , of a wave-length definition of the metre.

In this brief note one cannot hope to do full justice to the many activities reported, and the remaining comment will therefore be confined to a few points. For example, it is noticed that the National Standards Laboratory has been able to extend its help beyond the borders of Australia in the verification of standards of mass and that its own accuracy of weighing, already high, is to be refined by means of a special balance ordered for the purpose. The fact that the section leader responsible for this work is also concerned with such diverse matters as barometry, 